\title{
Development and field trial of a Tams1-targeted isothermal DNA amplification (Tams1-lamp) assay for detection of Theileria annulata in cattle
}

\author{
J Gomes ${ }^{1}$, A Amaro ${ }^{1 *}$, G Santos-Gomes², I Pereira da Fonseca ${ }^{3}$, J Inácio \\ From The 1st Conference on Neglected Vectors and Vector-Borne Diseases (EurNegVec): with Management \\ Committee and Working Group Meetings of the COST Action TD1303 \\ Cluj-Napoca, Romania. 8-11 April 2014
}

Mediterranean Theileriosis is frequently diagnosed in cattle in southern Portugal. This tick-borne hemoprotozoan disease, caused by the apicomplexan parasite Theileria annulata, poses important health problems in cattle in addition to the economic losses caused by decrease of productivity in chronic infected animals. Integrated control strategies for this disease will then benefit to the detection of cattle with chronic infection that usually acts as parasite reservoirs constituting a risk to susceptible animals. The highly sensitive and specific molecular methods for T. annulata detection are suitable for the identification of such animals often with very low parasitaemia. The isothermal amplification methods proved particularly useful for diagnostic laboratories with fewer resources since it does not require the use of expensive and sophisticated equipment such as thermal cyclers. In the present study we develop an isothermal amplification technique targeting Tams1 gene (Tams1-LAMP) for detection of T. annulata in cattle blood samples and compared this technique with real time PCR for assessing its applicability for diagnosis. One hundred blood samples from 16 farms were collected and analyzed. Genomic DNA extracted from blood was used as template in real time PCR and LAMP reactions for Tams1 gene amplification. A DNA sample extracted from T. annulata cell culture and one from an animal with $0.03 \%$ parasitaemia were used as positive controls. DNA samples from other closely related parasites were used as negative controls. The LAMP technique detection limit has been determined to correspond to a parasitaemia of approximately $0.008 \%$ and a specificity of $100 \%$. Real time PCR positive samples were detected in 14 farms with a

\footnotetext{
* Correspondence: ana.amaro@iniav.pt

'Instituto Nacional de Investigação Agrária e Veterinária, I.P. Lisbon, Portugal Full list of author information is available at the end of the article
}

total of $67 \%$ infected animals with very low parasitaemia that usually is characteristics of chronic infections. Tams1-LAMP identified 66\% infected animals from the 14 farms. Cohen's test was used to evaluate the agreement between methods and the $\mathrm{k}$ value found $(0.98)$ is indicative of an excellent agreement for this group of samples. These results permitted to conclude that Tams1-LAMP is a useful molecular technique to be applicable for detecting Theileria annulata in cattle with chronic infections.

\section{Authors' details}

'Instituto Nacional de Investigação Agrária e Veterinária, I.P. Lisbon, Portugal. ${ }^{2}$ Instituto de Higiene e Medicina Tropical, Lisbon, Portugal. ${ }^{3}$ Faculdade de Medicina Veterinária, Universidade Técnica de Lisboa, Portugal.

Published: 1 April 2014

doi:10.1186/1756-3305-7-S1-P5

Cite this article as: Gomes et al:: Development and field trial of a Tams 1-targeted isothermal DNA amplification (Tams1-lamp) assay for detection of Theileria annulata in cattle. Parasites \& Vectors 2014 7(Suppl 1):P5.

Submit your next manuscript to BioMed Central and take full advantage of:

- Convenient online submission

- Thorough peer review

- No space constraints or color figure charges

- Immediate publication on acceptance

- Inclusion in PubMed, CAS, Scopus and Google Scholar

- Research which is freely available for redistribution Submit your manuscript at
www.biomedcentral.com/submit C Biomed Central 